Article

\title{
A Comparative Analysis on Food Security in Bangladesh, India and Myanmar
}

\author{
Yuanyuan Chen ${ }^{1,2}$ and Changhe $\mathrm{Lu}^{1,2, *}$ \\ 1 Key Laboratory of Land Surface Pattern and Simulation, Institute of Geographic Sciences and Natural \\ Research, CAS, Beijing 100101, China; chenyy.15b@igsnrr.ac.cn \\ 2 College of Resources and Environment, University of Chinese Academy of Sciences, Beijing 100049, China \\ * Correspondence: luch@igsnrr.ac.cn; Tel.: +86-10-6488-9110
}

Received: 9 November 2017; Accepted: 1 February 2018; Published: 4 February 2018

\begin{abstract}
In 2013, China proposed the Bangladesh-China-India-Myanmar Economic Corridor initiatives to enhance the economic cooperation between Bangladesh, India, and Myanmar. To serve the priority setting of agricultural cooperation in the initiatives, an analysis is necessary to understand the food security situation and its key influencing factors in the three countries. For this purpose, this study applied a food security index (FSI) to measure the food security level at state scale and analyze its changes in the three countries during 1990-2013. Further, a factor decomposition method was used to quantify the contribution of major factors to the FSI changes. The results showed that the food demand was generally secured in Myanmar and India during 1990-2013 but in shortage by around $10 \%$ in most years before 2008 in Bangladesh. The annual FSI values showed a rather obvious periodic variation and a slightly increasing trend during the whole period. Although the grain production in the three countries increased significantly, the FSI was not accordingly improved, as a result of the simultaneous increase of grain consumption. In Bangladesh and India, the grain production increase was mainly driven by the improvement of crop yield, while the grain consumption increase was mainly caused by the population growth. In Myanmar, the production increase was largely caused by the expansion of cropping area, and the consumption growth was mainly due to the increased grain requirement per capita. To meet the increasing food demand in the future, it is essential to improve the irrigation and drainage systems and crop management to increase the land use efficiency and crop yield. In addition, the adaptation of appropriate policy for family planning could be important to slow down the quick population growth and thus the food demand.
\end{abstract}

Keywords: food security; food production and consumption; contribution factors; Bangladesh; India; Myanmar

\section{Introduction}

Food security is a situation that exists when all people, at all times, have physical, social, and economic access to sufficient, safe, and nutritious food that meets their dietary needs and food preferences for an active and healthy life [1]. After the 2008 global food price crisis, food security moved higher on the policy agenda in a number of countries [2], including Bangladesh [3], India [4], and Myanmar [5]. As these three countries all have a big population, together comprising $21 \%$ of the global population [6] and consuming 32\% of the global rice and 39\% of the global pulse [7], ensuring food security has been one of the major national priorities since their independence [8-10]. In 2013, China proposed the Bangladesh-China-India-Myanmar Economic Corridor initiatives to enhance economic cooperation. In this context, agricultural cooperation could be prioritized in the initiatives. Therefore, to serve the priority setting of agricultural cooperation, an analysis is needed to understand the food security situation and its key influencing factors in the three countries. 
Around 1990, Bangladesh, India, and Myanmar all started economic reforms, gradually liberalizing the food market and international trade, which greatly increased domestic food supplies [9-11]. Bangladesh has achieved self-sufficiency in rice with the accelerated growth of rice production in recent years after a steady growth since the 1970s [12-14]. In India, cereal production increased by more than 70\% during 1980-2007 [15], and in Myanmar, rice, pulse, and maize production have all shown remarkable growth since 1988 [16,17]. Excepting the economic reforms and adaptation of appropriate policy measures $[9,11,18,19]$, the increased agricultural inputs [20-23] and the adjustment of land use [24-26] played key roles in the increase of grain production. Regarding the food security issue, the food production and consumption changes and their influencing factors during the past decades for individual countries have been well-documented by current studies. However, the actual level and changing trend of food security in the three countries have not been clearly analyzed yet. Therefore, considering the policy change and data availability, this study selected 1990-2013 as the study period, and adopted a food security index (FSI) as an indicator to comparatively examine the food security level and its change in Bangladesh, India, and Myanmar. Then, the Logarithmic Weight Mean Division Index (LMDI), a factor decomposition analysis approach, was applied to quantify the contribution of major affecting factors to the food security change. Finally, suggestions for improving food security were given.

\section{Data and Methods}

\subsection{Data}

The data of food production and consumption, agricultural inputs, and population were collected from various sources for the period of 1990-2013. Arable land area, cropping index (the average number of crops planted on the same plot of cropland in one year), harvest area and yield of food crops (rice, wheat, maize, and pulses), and agricultural inputs were collected from the Yearbook of Agricultural Statistics of Bangladesh, State Wise Area Production \& Yield Statistics of India (http://eands.dacnet.nic.in/MSP.htm), Statistical Yearbook of India, Yearbook of Agricultural Statistics of Myanmar, and Myanmar Statistical Yearbook. Total grain production and food consumption for each of the three countries were derived from the FAO food balance sheets. Population size was based on the estimated data by the Population Division of the United Nations (http://www.un.org/en/development/desa/population/).

In this study, production and consumption of wheat, maize, and pulses were converted to rice equivalents $(\mathrm{RE})$ with the conversion ratio $\left(\mathrm{CF}_{\mathrm{i}}\right)$ of $1.02,1.03$, and 1.18 , respectively, which were calculated with the following equation [27]:

$$
\mathrm{CF}_{\mathrm{i}}=\frac{\mathrm{H}_{\mathrm{i}}}{\mathrm{H}_{0}} \times 0.9+\frac{\mathrm{P}_{\mathrm{i}}}{\mathrm{P}_{0}} \times 0.1
$$

where $\mathrm{H}_{\mathrm{i}}$ is the content of calories and $\mathrm{P}_{\mathrm{i}}$ protein in food crop $\mathrm{i}$, and $\mathrm{H}_{0}$ and $\mathrm{P}_{0}$ are the content in rice, respectively.

\subsection{Methods}

\subsubsection{Indicator of Food Security}

This study adopted the food self-sufficiency ratio, a commonly used indicator to measure the food security at national level [28-34]. This ratio is defined as the share of domestic food grain production in the total domestic consumption [35], and is called the food security index (FSI) in this study. It is presented in the equation below:

$$
\text { FSI }=\frac{\text { TGP }}{\text { TGC }}=\frac{\sum_{i=1}^{\mathrm{n}} \mathrm{GP}_{\mathrm{i}}}{\sum_{\mathrm{i}=1}^{\mathrm{n}} \text { Food }_{\mathrm{i}}+\text { Feed }_{\mathrm{i}}+\text { Other }_{\mathrm{i}}}
$$


where TGP is the total domestic grain production, i.e., the summation of rice, wheat, maize, and pulses (denoted separately as $\mathrm{GP}_{\mathrm{i}}$ ) in rice equivalent. TGC is the total grain consumption, i.e., the summation of the grain types consumed for food $\left(\right.$ Food $\left._{i}\right)$ and feed $\left(\mathrm{Feed}_{\mathrm{i}}\right)$, as well as the part used for seeds, and losses during processing and storage (denoted as $\mathrm{Other}_{\mathrm{i}}$ ).

\subsubsection{Quantifying Factor Contribution to Food Security}

Total grain production (TGP) and total grain consumption (TGC), as well as four major factors including total cropping area (TCA), mean crop yield (MCY), total population (TP), and per capita grain consumption (PCGC), were analyzed to quantify their contribution to the FSI change during 1990-2013, using the Logarithmic Weight Mean Division Index (LMDI) method. The LMDI can eliminate the residual and " 0 " value in the decomposition process and improve the accuracy of the analysis [36]. It has been used in analyzing grain production driving factors and their contribution [37-40].

According to LMDI, the change in the FSI during a given period, $\triangle F S I$, can be decomposed as follows:

$$
\Delta \mathrm{FSI}=\Delta \mathrm{TGP}+\Delta \mathrm{TGC}
$$

where $\triangle \mathrm{TGP}$ is the part of $\triangle \mathrm{FSI}$ induced by the change in TGP, and $\triangle \mathrm{TGC}$ is the part induced by the change in TGC. For the given period between the beginning time 0 and the ending time $t, \triangle T G P$ and $\triangle T G C$ can be quantified by the following equations [36]:

$$
\Delta \mathrm{TGP}=\frac{\mathrm{GSI}_{\mathrm{t}}-\mathrm{GSI}_{0}}{\ln \mathrm{GSI}_{\mathrm{t}}-\ln \mathrm{GSI}_{0}} \ln \frac{\mathrm{GP}_{\mathrm{t}}}{\mathrm{GP}_{0}} ; \Delta \mathrm{TGC}=\frac{\mathrm{GSI}_{\mathrm{t}}-\mathrm{GSI}_{0}}{\ln \mathrm{GSI}_{\mathrm{t}}-\ln \mathrm{GSI}_{0}} \ln \frac{\mathrm{GC}_{0}}{\mathrm{GC}_{\mathrm{t}}}
$$

$\triangle \mathrm{TGP}$ is further decomposed as two parts, i.e., the part contributed by changes in the sowing area and the part contributed by changes in the crop yield. Similarly, $\triangle \mathrm{TGC}$ is also decomposed as two parts, i.e., the contribution of population changes and PCGC changes, respectively. $\triangle T G P$ and $\triangle T G C$ are presented as follows:

$$
\Delta \mathrm{TGP}=\Delta \mathrm{TCA}+\Delta \mathrm{MCY} ; \Delta \mathrm{TGC}=\Delta \mathrm{TP}+\Delta \mathrm{PCGC}
$$

where $\triangle \mathrm{TCA}$ and $\triangle \mathrm{MCY}$ are the part of $\triangle \mathrm{TGP}$ caused by changes in the total crop sowing area and crop yield; $\triangle \mathrm{TP}$ and $\triangle \mathrm{PCGC}$ are the part of $\triangle \mathrm{TGC}$ caused by changes in population size and per capita grain consumption, respectively. Similar to Equation (4), $\triangle \mathrm{TCA}, \triangle \mathrm{MCY}, \triangle \mathrm{TP}$, and $\triangle \mathrm{PCGC}$ can be calculated as follows:

$$
\begin{aligned}
& \Delta \mathrm{TCA}=\frac{\mathrm{TGP}_{\mathrm{t}}-\mathrm{TGP}_{0}}{\ln \mathrm{TGP}_{-}-\ln \mathrm{TGP}_{0}} \ln \frac{\mathrm{TCA}_{\mathrm{t}}}{\mathrm{TCA}_{0}} ; \Delta \mathrm{MCY}=\frac{\mathrm{TGP}_{\mathrm{t}}-\mathrm{TGP}_{0}}{\ln \mathrm{TGP}_{\mathrm{t}}-\ln \mathrm{TGP}_{0}} \ln \frac{\mathrm{MCY}_{\mathrm{t}}}{\mathrm{MCY}_{0}} ; \\
& \Delta \mathrm{TP}=\frac{\mathrm{TGC}_{\mathrm{t}}-\mathrm{TGC}_{0}}{\ln \mathrm{TGC}_{\mathrm{t}}-\ln \mathrm{TGC}_{0}} \ln \frac{\mathrm{TP}_{\mathrm{t}}}{\mathrm{TP}_{0}} ; \Delta \mathrm{PCGC}=\frac{\mathrm{TGC}_{\mathrm{t}}-\mathrm{TGC}_{0}}{\ln \mathrm{TGC}_{\mathrm{t}}-\ln \mathrm{TGC}_{0}} \ln \frac{\mathrm{PCGC}_{\mathrm{t}}}{\mathrm{PCGC}_{0}}
\end{aligned}
$$

The contribution proportion (\%) of $\triangle \mathrm{TCA}$ and $\triangle \mathrm{MCY}$ to $\triangle \mathrm{TGP}$ is denoted as $\mathrm{C}_{\mathrm{TCA}}$ and $\mathrm{C}_{\mathrm{MCY}}$, and the contribution of $\triangle \mathrm{TP}$ and $\triangle \mathrm{PCGC}$ to $\triangle \mathrm{TGC}$ is denoted as $\mathrm{C}_{\mathrm{TP}}$ and $\mathrm{C}_{\mathrm{PCGC}}$, respectively, which are calculated with the following equations:

$$
\begin{aligned}
& \mathrm{C}_{\mathrm{TCA}}=\frac{\Delta \mathrm{TCA}}{\Delta \mathrm{TGP}} \times 100 ; \mathrm{C}_{\mathrm{MCY}}=\frac{\Delta \mathrm{MCY}}{\Delta \mathrm{TGCP}} \times 100 \\
& \mathrm{C}_{\mathrm{TP}}=\frac{\Delta \mathrm{TP}}{\Delta \mathrm{TGC}} \times 100 ; \mathrm{C}_{\mathrm{PCGC}}=\frac{\Delta \mathrm{PCGC}}{\Delta \mathrm{TGC}} \times 100
\end{aligned}
$$

The positive value for a factor indicates a positive contribution to the change in FSI; otherwise, it is a negative contribution.

\section{Results}

\subsection{Food Security and Its Changing Trends}

Food security level, i.e., the FSI in 2013 was 1.02 in Bangladesh, 1.08 in India, and 1.09 in Myanmar, implying that the food production slightly exceeded the consumption at the national level. From 1990 
to 2013 , the FSI showed a rather obvious periodic variation and a slightly increasing trend (Figure 1). In Bangladesh, the FSI increased from 0.88 to 0.91 in 1990-1993, and declined to 0.83 in 1994. From 1995 to 2000 , it increased significantly to 0.95 , and then declined again to 0.82 in 2004 . After that, it was gradually elevated to 1.00 in 2008 and remained around 1.01 during 2009-2013. Similarly, the FSI in Myanmar also fluctuated periodically: after an increase from 1.06 in 1990 to 1.17 in 1994, the FSI dropped to 1.08 in 1998, and then increased to 1.18 in 2003. After a decrease to 1.13 in 2005, the FSI increased again to 1.22 in 2009, and then quickly declined to 1.09 in 2013. In India, the FSI varied slightly around 1.01 during 1990-2008 except for a significant decline in 2002. After a small decrease in 2009, it continuously increased to 1.11 in 2012 and then decreased to 1.09 in 2013. The results indicate that food consumption was safely secured in Myanmar and India in all years of the period studied, but was in shortage by around 10\% in most years before 2008 in Bangladesh. During the last 5-6 years, the food security level was obviously improved in Bangladesh and India, but evidently decreased in Myanmar (Figure 1).

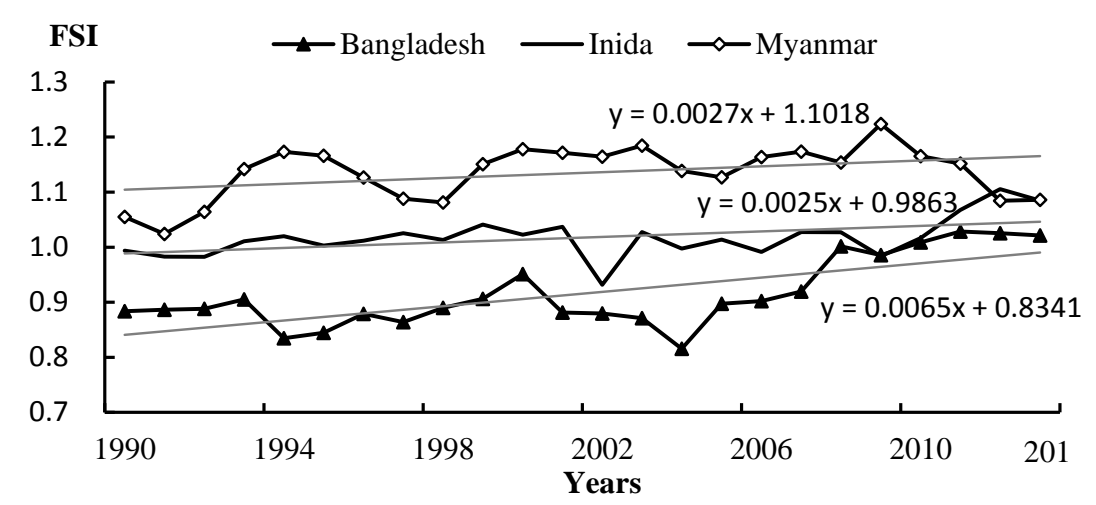

Figure 1. Annual variation of food security index (FSI) in the three countries during 1990-2013.

\subsection{Causal Factors and Their Effect on FSI}

Table 1 presents the LMDI decomposition results. The grain production showed a positive contribution to the FSI, but the grain consumption showed a negative effect during 1990-2013. With the joint influences of both, the FSI increased by $0.0028-0.0060$ per year, implying that the contribution of increased TGP was largely offset by the increased TGC, thus the FSI was not evidently improved during the period studied.

Table 1. Changes in FSI caused by grain production and demand and the contributions of factors.

\begin{tabular}{|c|c|c|c|c|c|c|c|}
\hline \multirow{2}{*}{ Country } & \multicolumn{3}{|c|}{ Production } & \multicolumn{3}{|c|}{ Consumption } & \multirow{2}{*}{$\Delta \mathrm{FSI}$} \\
\hline & $\Delta \mathrm{TGP}$ & $\mathrm{C}_{\mathrm{TCA}}$ & $\mathrm{C}_{\mathrm{MCY}}$ & $\Delta \mathrm{TGC}$ & $\mathrm{C}_{\mathrm{TP}}$ & $\mathrm{C}_{\text {PCGC }}$ & \\
\hline Bangladesh & 0.0262 & $12.03 \%$ & $87.97 \%$ & -0.0202 & $76.62 \%$ & $23.38 \%$ & 0.0060 \\
\hline India & 0.0187 & $2.25 \%$ & $97.75 \%$ & -0.0147 & $114.91 \%$ & $-14.91 \%$ & 0.0040 \\
\hline Myanmar & 0.0522 & $81.40 \%$ & $18.60 \%$ & -0.0494 & $22.86 \%$ & $77.14 \%$ & 0.0028 \\
\hline
\end{tabular}

The data in Table 1 indicate that the crop yield improvement contributed $88 \%$ and $98 \%$ to the $\triangle \mathrm{TGP}$, and the population growth contributed $77 \%$ and $115 \%$ to the $\triangle$ TGC during 1990-2013 in Bangladesh and India, respectively. These imply that the FSI changes were largely determined by the crop yield improvement and population growth in both countries. In India, the PCGC showed a positive contribution to the FSI, because it decreased during the period studied. By contrast, in Myanmar the main contributor to the $\triangle \mathrm{TGP}$ was the expansion of crop sowing area $(81 \%)$, and the main contributor to the $\triangle \mathrm{TGC}$ was the increased food consumption per capita $(77 \%)$. Therefore, the FSI change was mainly determined by the changes in the cropping area and per capita food consumption in Myanmar. 


\section{Discussion}

\subsection{Food Security Variations}

The results indicate that the food security level, i.e., the FSI in the three countries increased slightly from 1990 to 2013, and the food grain production exceeded the consumption at the national level in 2013. A study by Del Ninno et al. also indicated that Bangladesh and India have achieved great success in raising domestic production and thus gradually reduced the level of food aid received since 1981 [9]. The grain import dependency has declined to less than $10 \%$ since 1991 and rice has been self-supplied since 2011 in Bangladesh [41]. Grain production has exceeded the demand in India since the early 1980s. In Myanmar, rice retained export steadily during 1988-2012 [42].

The FSI variation was mainly caused by unpredictable natural disasters, as the agriculture development of the three countries relies rather heavily on the monsoon rains and is vulnerable to natural disasters such as floods and droughts [9,43]. For the years with a significant decrease in the FSI, severe droughts or floods were observed. For instance, in 1994 in Bangladesh, and in 2002 and 2009 in India, severe droughts were reported to have caused great yield reductions [44,45]. In 2000-2004, more frequent rainstorms and flooding were observed in Bangladesh, causing more damage to food production than in normal years [46]. In Myanmar, a severe flood in 1996 caused extensive damage to rice and yield reduction [16], resulting in the FSI decrease.

The difference in FSI among the three countries was generally determined by the available land resources, crop management, and policies. Bangladesh had a large population of 160 million in 2015 [6], but very limited available land (less than 0.1 ha per capita). Due to poor irrigation and drainage systems [8], the agriculture was frequently affected by droughts and floods [47]. Similarly, India has also faced the pressure of a large population, but it has relatively rich arable land resources, and a higher ability to improve the agricultural technology and thus crop productivity. In contrast, Myanmar has rich land resources and was already a large rice producer before its independence [48]. After gaining its independence, the new government has regarded a stable supply of rice as a prerequisite for political stability [10], and thus has made great efforts to improve agriculture, making Myanmar a big rice exporter.

\subsection{Food Production}

Total food production in Bangladesh, India, and Myanmar showed a significantly increasing trend during 1990-2013 (Figure 2), increasing on average by $92.55 \%, 52.68 \%$, and 165.73\%, respectively, resulting in the improvement of the FSI. A correlation analysis indicated that changes in the annual FSI and food production were significantly correlated in the three countries with the coefficient of determination $\left(\mathrm{R}^{2}\right)$ of $0.844,0.917$, and 0.519 , respectively. Compared with the annual change in the FSI (Figure 1), total food production in the three countries showed a similar annual variation trend.

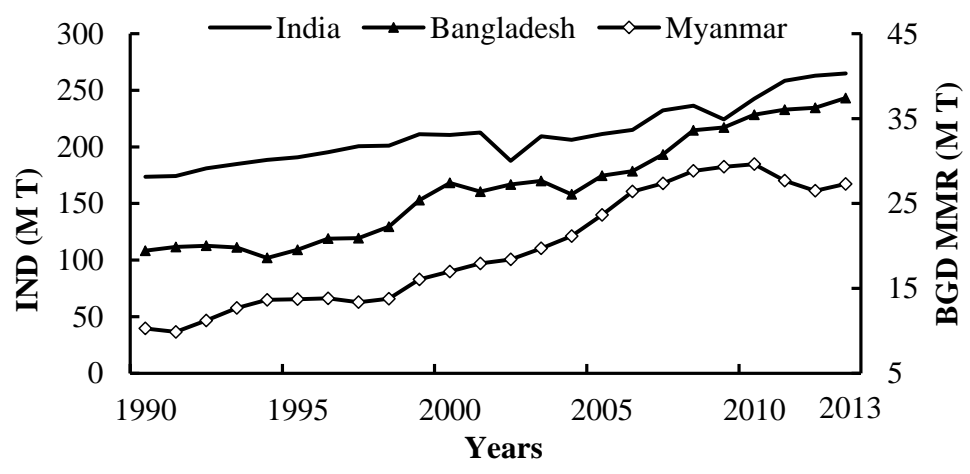

Figure 2. Annual variation of total grain production in India (IND), Bangladesh (BGD) and Myanmar (MMR) during 1990-2013. 
The rapid growth of total grain production in Bangladesh and India was mainly achieved by the crop yield improvement, while in Myanmar it was mainly achieved by the cropping area expansion (Table 2). From 1990 to 2013, crop harvest area was expanded by only 7.23\% in Bangladesh, but the mean crop yield increased by $79.57 \%$, contributing $87.97 \%$ to the production increase. Similarly, in India, the cropping area increased slightly by $1.12 \%$, but the crop yield increased by $51.00 \%$, contributing $97.75 \%$ to the total grain production. In Myanmar, the crop yield increased by $14.62 \%$, but the harvest area expanded by $131.84 \%$, which contributed $81.4 \%$ to the production increase.

Table 2. Change of mean yield (RE) and total area of grain crops in the three countries.

\begin{tabular}{ccccc}
\hline Country & Indicator & $\mathbf{1 9 9 0}$ & $\mathbf{2 0 1 3}$ & Total Increase (\%) \\
\hline \multirow{2}{*}{ Bangladesh } & Crop area (M ha) & 11.87 & 12.73 & 7.23 \\
& Yield (kg/ha) & 1636.58 & 2938.88 & 79.57 \\
\hline \multirow{2}{*}{ India } & Crop area (M ha) & 125.95 & 127.36 & 1.12 \\
& Yield (kg/ha) & 1377.70 & 2080.27 & 51.00 \\
\hline \multirow{2}{*}{ Myanmar } & Crop area (M ha) & 4.21 & 9.76 & 131.84 \\
& Yield (kg/ha) & 2440.11 & 2796.75 & 14.62 \\
\hline
\end{tabular}

The quick yield improvement in Bangladesh was mainly due to the large expansion of the high yielding rice variety, Boro rice, which grows in the dry season with irrigation [14], and has a much higher yield than Aus and Aman rice. Promoted by the government policies that encourage private development and allow private purchases of agricultural equipment such as pumps [49], the area irrigated by power pumps and tube wells increased by 1.80 and 2.74 times during 1990-2013 [46]. Associated with this irrigation improvement, the sowing area of Boro rice expanded significantly by $104.07 \%$ from 2.37 to $4.48 \mathrm{M}$ ha (Table 3). Irrigation with groundwater has the ability to supply the required water on time, and thus can achieve higher crop yields than irrigation with surface water [22]. In India, the yield increase was mainly attributed to the "Green Revolution" that was implemented between the mid-1960s and the early 2000s [50], which aimed to change the heavy dependence on food aid of about two decades since the independence [15], and to ensure food self-sufficiency [9]. This program includes many improved practices such as increasing public investments in agricultural research and extension, improving irrigation levels, strengthening plant protection, and increasing fertilizers and pesticide use [9,50]. With these practices, the irrigation conditions have greatly improved and agricultural inputs have markedly enhanced (Table 3) and thus promoted the yield increase. Meanwhile, the cropping structure has been largely adjusted: the sowing area of low-yielding crops jowar and bajra was reduced by $57.09 \%$ and $30.15 \%$, while high-yielding crops of rice, wheat, and maize expanded by $3.34 \%, 30.20 \%$, and $55.56 \%$, respectively (Table 3 ).

In Myanmar, the government has believed that the stable supply of rice is a prerequisite for political stability since 1988 [10]. To promote agricultural development and food production, the government enacted two legal documents in 1991 and 1998 to encourage farmers to make full use of unused and fallow lands [51]. Promoted by this policy, the sowing area of rice, maize, and pulses increased by $46.07 \%, 251.78 \%$, and $394.83 \%$, respectively, with the cropping index increased accordingly by $31.97 \%$ during 1990-2013 (Table 3). Meanwhile, the Ministry of Agriculture and Irrigation has taken many measures to increase crop yield, including improving irrigation systems and mechanization levels, and increasing fertilizer and pesticide applications [51]. In addition, the trade liberalization stimulated the increase of the domestic price of pulses, and thus resulted in the dramatic expansion of the pulse sowing area [52]. 
Table 3. Change of sown area of main crops and inputs in the three countries.

\begin{tabular}{|c|c|c|c|c|}
\hline Country & Indicator & 1990 & 2013 & Total Increase (\%) \\
\hline \multirow{8}{*}{ Bangladesh } & Arable land area (M ha) & 8.17 & 7.92 & -3.06 \\
\hline & Cropping index $(\%)$ & 171.70 & 191.88 & 20.18 \\
\hline & Acreage of Aus rice (M ha) & 1.93 & 1.05 & -45.69 \\
\hline & Acreage of Aman rice (M ha) & 5.80 & 5.53 & -4.65 \\
\hline & Acreage of Boro rice (M ha) & 2.37 & 4.84 & 104.07 \\
\hline & Irrigation area of Boro rice ( $\mathrm{M} \mathrm{ha}$ ) & 1.82 & 4.62 & 254.10 \\
\hline & Fertilizer $(\mathrm{kg} / \mathrm{ha})$ & 148.76 & 176.02 & 18.32 \\
\hline & Pesticide (kg/ha) & - & 2.48 & - \\
\hline \multirow{12}{*}{ India } & Arable land area (M ha) & 142.87 & 141.43 & -1.01 \\
\hline & Cropping index $(\%)$ & 130.01 & 142.02 & 12.01 \\
\hline & Acreage of rice (M ha) & 42.69 & 44.11 & 3.34 \\
\hline & Acreage of wheat (M ha) & 24.17 & 31.47 & 30.20 \\
\hline & Acreage of jowar (M ha) & 14.36 & 6.16 & -57.09 \\
\hline & Acreage of bajra (M ha) & 10.48 & 7.32 & -30.15 \\
\hline & Acreage of maize (M ha) & 5.90 & 9.19 & 55.56 \\
\hline & Irrigation area (M ha) & 42.29 & 58.40 & 38.09 \\
\hline & Irrigation area percent $(\%)$ & 40.99 & 58.13 & 17.14 \\
\hline & Fertilizer (kg/ha) & 98.14 & 195.80 & 99.51 \\
\hline & Pesticide (kg/ha) & - & 0.60 & - \\
\hline & Electricity $\left(10^{13} \mathrm{~W}\right)$ & 5.03 & 14.75 & 193.24 \\
\hline \multirow{10}{*}{ Myanmar } & Arable land area (M ha) & 8.32 & 13.36 & 60.51 \\
\hline & Cropping index (\%) & 121.66 & 161.16 & 39.50 \\
\hline & Acreage of rice (M ha) & 4.76 & 6.95 & 46.07 \\
\hline & Acreage of wheat (M ha) & 0.14 & 0.10 & -25.82 \\
\hline & Acreage of maize (M ha) & 0.13 & 0.44 & 251.78 \\
\hline & Acreage of pulse (M ha) & 0.86 & 4.26 & 394.83 \\
\hline & Irrigation area $(\mathrm{M}$ ha) & 0.92 & 2.16 & 134.59 \\
\hline & Irrigation area $(\%)$ & 15.18 & 17.99 & 2.81 \\
\hline & Fertilizer (kg/ha) & - & 4.38 & - \\
\hline & Pesticide (kg/ha) & 0.03 & 0.47 & $1466.67-$ \\
\hline
\end{tabular}

Note: "-" stand for no data. The fertilizer was a physical quantity. The pesticide included powdered and liquid pesticides.

\subsection{Food Consumption}

From 1990 to 2013, total grain consumption in Bangladesh, India, and Myanmar increased (Figure 3) significantly by $66.6 \%, 39.89 \%$, and $158.11 \%$, with an annual growth rate of $2.28 \%, 1.49 \%$, and $4.30 \%$, respectively. This increase was rather close to (slightly lower than) that of the grain production, largely offsetting the contribution of food production increase to the FSI. In the increase of total grain consumption, $74.76 \%$ and $113.09 \%$ were attributed to the population growth in Bangladesh and India, respectively, but $76.12 \%$ was contributed by the increase of per capita grain consumption in Myanmar (Table 4). This difference was because the population growth was much lower in Myanmar than in Bangladesh and India, and because of that the great increase in feed requirement for producing the animal foods of meat, eggs, and milk (Table 5) increased the grain consumption in Myanmar. In addition, total grain consumption per capita changed relatively little in Bangladesh and India (Table 4). 


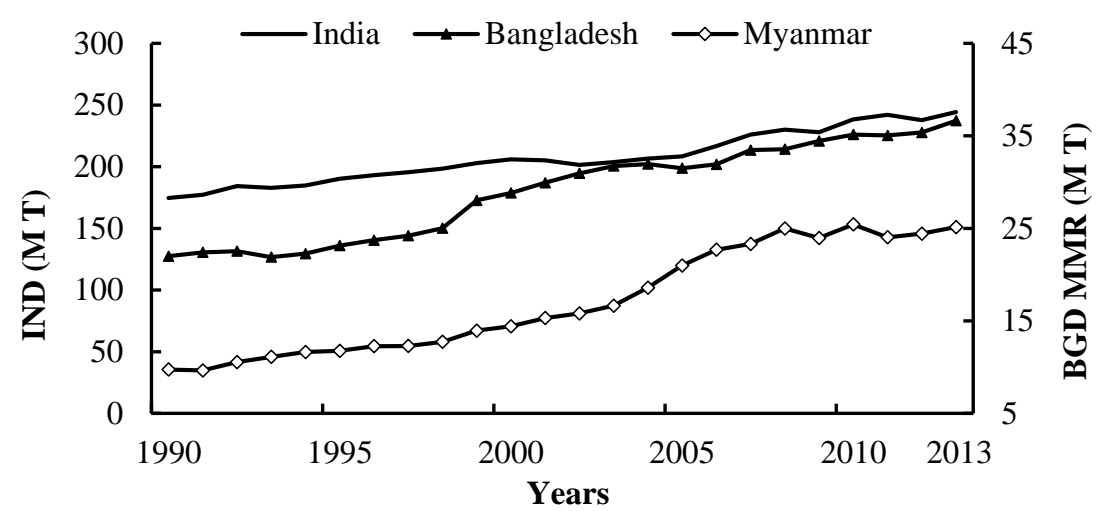

Figure 3. Annual variation of total grain consumption of the three countries during 1990-2013.

Table 4. Change of population and per capita grain consumption (rice equivalents) in the three countries.

\begin{tabular}{ccccc}
\hline Country & Indicator & $\mathbf{1 9 9 0}$ & $\mathbf{2 0 1 3}$ & Total Increase (\%) \\
\hline \multirow{5}{*}{ Bangladesh } & Population (M) & 105.98 & 157.16 & 48.29 \\
& Consumption (kg) & 207.52 & 233.15 & 12.35 \\
& Food (kg) & 190.71 & 197.12 & 3.36 \\
& Feed (kg) & 3.41 & 17.41 & 410.80 \\
& Others (kg) & 13.39 & 18.62 & 39.00 \\
\hline \multirow{5}{*}{ India } & Population (M) & 870.60 & 1279.50 & 46.97 \\
& Consumption (kg) & 200.58 & 190.93 & -4.81 \\
& Food (kg) & 179.55 & 163.36 & -9.02 \\
& Feed (kg) & 5.06 & 10.81 & 113.45 \\
& Others (kg) & 15.96 & 16.75 & 4.96 \\
\hline \multirow{5}{*}{ Myanmar } & Population (M) & 42.01 & 52.98 & 26.13 \\
& Consumption (kg) & 231.82 & 474.40 & 104.64 \\
& Food (kg) & 131.53 & 162.35 & 23.43 \\
& Feed (kg) & 60.96 & 227.09 & 272.53 \\
& Others (kg) & 39.34 & 84.96 & 115.99 \\
\hline
\end{tabular}

Table 5. Change of per capita food consumption $(\mathrm{kg})$ in the three countries.

\begin{tabular}{ccccccc}
\hline Country & Years & Cereals & Pulses & Meat & Eggs & Milk \\
\hline \multirow{2}{*}{ Bangladesh } & 1990 & 183.44 & 6.16 & 2.91 & 0.64 & 14.04 \\
& 2013 & 189.40 & 6.55 & 4.00 & 2.07 & 21.83 \\
\hline \multirow{2}{*}{ India } & 1990 & 162.46 & 13.11 & 3.95 & 0.23 & 104.89 \\
& 2013 & 145.28 & 14.09 & 3.49 & 0.51 & 165.39 \\
\hline \multirow{2}{*}{ Myanmar } & 1990 & 124.81 & 5.69 & 6.45 & 1.57 & 24.23 \\
& 2013 & 145.80 & 14.02 & 53.16 & 12.95 & 63.30 \\
\hline
\end{tabular}

During 1990-2013, the per capita consumption of cereals and pulses increased slightly, but livestock products increased significantly in Bangladesh and Myanmar (Table 5). As a result, the per capita grain consumption for feed increased by $410.8 \%$ and $272.53 \%$ in the two countries (Table 4 ), which contributed $54.62 \%$ and $69.48 \%$ to the per capita grain consumption increase, respectively. The dietary change in India was different. From Table 5, it can be seen that the per capita consumption of cereals for food decreased by $17.18 \mathrm{~kg}$, and meat decreased by $0.46 \mathrm{~kg}$, while egg and milk consumptions increased by $0.28 \mathrm{~kg}$ and $60.5 \mathrm{~kg}$, respectively. As production of milk required little grain but more forage [53], in spite of the big increase in milk consumption, the increase of grain consumed as feed in India was relatively low compared to Bangladesh and Myanmar (Table 4). 
The dietary change was mainly driven by the improvement of gross national income (GNI), as increased incomes can improve the food purchasing ability and lead to major shifts in demand from inferior foods towards more varied and higher value foods [54,55]. During 1990-2013, the per capita GNI in the three countries increased by $2.91,3.13$, and 8.17 times, respectively [56]. The correlation analysis indicated that the consumption of livestock products per capita (in calories) was significantly related to the per capita GNI in Bangladesh, India, and Myanmar with correlation coefficients $\left(R^{2}\right)$ of $0.962,0.978$, and 0.909 , respectively. For the decline in cereal consumption in India with rising incomes, a well-accepted explanation is that the increased agricultural mechanization has reduced physical activity and thus calorie requirements $[57,58]$. The significant increase in milk consumption could also be a reason for the reduction of grain requirement.

Excepting the increased incomes, religious taboos and the caste system have also greatly influenced the consumption level and change of livestock product consumption in Bangladesh and India. Pork has not been allowed in Islam and beef has been forbidden in Hinduism [59], which greatly restricted the consumption of meats in both countries. The caste system also has great impact on the food consumption in India, as it plays a role in determining physical and economic access to food [60]. For example, members of the Brahman caste (the highest grade in Indian society) should be vegetarian but can consume milk and milk products [59]. Although the legal status of the caste system has been formally abolished, it still plays a very important role in India, especially in rural areas [61].

\subsection{Policy Implications}

Presently, the dietary level with the energy and protein largely taken from plant foods in the three countries is lower than the world average. In 2013, about $90 \%$ of the calorie intake was from rice in Bangladesh, while $68 \%$ in India and $66 \%$ in Myanmar were from cereals. Although the total annual intake of grains (including cereals and pulses) per capita in Bangladesh, India, and Myanmar (Table 5) exceeded slightly the world average of $155.57 \mathrm{~kg}$, the daily energy intake from livestock products was only 64,154 , and $387 \mathrm{kcal}$, respectively, all lower than the world average of $411 \mathrm{kcal} /$ day [7]. According to FAO estimates, the daily energy intake per capita is $2450 \mathrm{kcal}$ in Bangladesh, $2459 \mathrm{kcal}$ in India, and $2571 \mathrm{kcal}$ in Myanmar, all lower than the world average of $2884 \mathrm{kcal} /$ day, and $16.4 \%$, $15.2 \%$, and $14.2 \%$ of the population were reported as undernourished, respectively, much higher than the world average of $10.9 \%$ [62]. Moreover, $36.1 \%, 38.4 \%$, and $29.2 \%$ of children were reported being stunted in the three countries, respectively, also higher than the world average of $27.8 \%$ [63]. These figures imply that the food supplies are unevenly distributed in the countries, and there is still a large population without access to sufficient food supply. With population growth that was predicated to increase by 25, 217, and 6 million in 2030 in Bangladesh, India, and Myanmar, respectively [6], and with the dietary improvement, total grain demand will continue to increase in the coming decades, especially in Bangladesh and India. With global warming, the frequency and intensity of droughts and floods are predicted to increase, and the rising sea level might cause inundation of the productive lands, resulting in adverse impacts on the food production in the three countries [64-67].

To meet the increasing food demand, the first step should aim to improve crop productivity. In 2013, the mean crop yield was only 2.94, 2.08, and $2.80 \mathrm{t} / \mathrm{ha}$ in Bangladesh, India, and Myanmar, respectively, about half of that in China. This low yield is mainly due to damage by pests and diseases, shortages of agricultural machinery and fertilizers, insufficient irrigation and drainage systems, and poor land management $[5,68]$. Therefore, there is still a high potential to increase crop yield to meet the food demand. To exploit this potential, there is a need to further improve the irrigation and drainage systems, increase rice yield in the dry season, and reduce the damage of flooding in the rainy season. The rice-based mono-cropping structure widely practiced, particularly in Bangladesh, could be appropriately diversified by adopting crop rotation systems, which can reduce the occurrence of pests and diseases and improve soil fertility [69]. In addition, enhancing the agricultural extension services could be helpful for small-scale farmers to select appropriate technologies and high-quality seeds, to improve crop management, and to optimize fertilizer and 
pesticide use. The second is to promote the efficient use of the arable land resources. In the three countries, most arable lands are suitable to grow 2-3 seasons of crops a year, but the cropping index is rather low at present (Table 3). In Myanmar, a total of $5.7 \mathrm{M}$ ha (about half of the total grain crop area) of land is currently fallow or unused [70]. Sufficient use of the farmland by increasing the cropping index should be considered to increase food production. The third is the protection of arable land resources, particularly in Bangladesh, where arable land losses are rather serious due to urban land and brickyard occupations. In addition, measures should be developed to prevent the land from encroachments of sea water that will probably increase with the rising sea level under global warming. Finally, an appropriate policy for family planning could be important to slow down the quick population and food demand growth. China has lots of experience in the development of agricultural irrigation and drainage systems, water-saving irrigation technologies, formula fertilization, rice seed breeding, and small household-based farming technologies. This experience can be the basis for seeking agricultural cooperation with the three countries in the Bangladesh-China-India-Myanmar Economic Corridor initiatives.

\section{Conclusions}

This study examined the change and trend of food security in Bangladesh, India, and Myanmar during 1990-2013, and then quantified the contribution of major affecting factors. The main conclusions are summarized below:

(1) The food security level, i.e., the FSI in Bangladesh, India, and Myanmar, was rather similar, with the values of 1.02, 1.08, and 1.09 in 2013, respectively. During 1990-2013, the food consumption was generally met by the production at the national level in Myanmar and India, but it was in shortage of around 10\% in most years before 2008 in Bangladesh. The FSIs all showed a rather obvious periodic variation and a slightly increasing trend during the period studied. It was observed that the FSI was obviously improved in Bangladesh and India but decreased in Myanmar during 2009-2013.

(2) During 1990-2013, the grain production and consumption in the three countries all showed a significantly increasing trend at a rather similar pace. As a result, the food security level was not evidently improved, because the increasing grain consumption largely offset the positive contribution of the grain production increase. In Bangladesh and India, the increase of total grain production was mainly caused by the improvement of crop yield, and the increase of grain consumption was mainly driven by the growth of population. In Myanmar, the crop area expansion was the main contributor to the grain production increase, while the increase of grain consumption per capita was the main factor in the increase of total grain demand.

(3) To meet the increasing food demand, the emphasis should be put on the promotion of efficient use of land resources and raising crop yield, by improving the irrigation and drainage systems and crop management. In addition, the adaptation of appropriate policy for family planning could be important to slow down the quick population growth and thus the food demand.

Acknowledgments: This work was supported by The Chinese Academy of Sciences Key Deployment Project (ZDRW-ZS-2016-6-4-3). And we have received funds for covering the costs to publish in open access. We appreciate the constructive comments from the two anonymous reviewers.

Author Contributions: Changhe Lu conceived and designed the research topic, and wrote and revised the manuscript; Yuanyuan Chen detailed the research procedure, analyzed the data, and wrote the manuscript.

Conflicts of Interest: The authors declare no conflict of interest.

\section{References}

1. FAO. Rome Declaration on World Food Security; FAO: Rome, Italy, 1996.

2. Barrett, C.B. Measuring food insecurity. Science 2010, 327, 825-828. [CrossRef] [PubMed] 
3. Dorosh, P.A.; Rashid, S. Bangladesh Rice Trade and Price Stabilization: Implications of the 2007/08 Experience for Public Stocks; International Food Policy Research Institute: Washington, DC, USA, 2012.

4. Lijun, C. Impact of the world "food crisis" on India's food security. Southeast Asian South Asian Stud. 2009, 3, $40-45$.

5. Zhijian, K. A primary study on the current situation and prospects for Myanmar's agricultural development. J. Nanning Polytech. 2011, 16, 37.

6. UN. UN World Population Prospects: The 2015 Revision; United Nations, Department of Economic and Social Affairs, Population Division: New York, NY, USA, 2017.

7. FAOSTAT. Food Balance Sheet; FAO: Rome, Italy, 2017.

8. Faisal, I.M.; Parveen, S. Food security in the face of climate change, population growth, and resource constraints: Implications for Bangladesh. Environ. Manag. 2004, 34, 487-498. [CrossRef] [PubMed]

9. Del Ninno, C.; Dorosh, P.A.; Subbarao, K. Food aid, domestic policy and food security: Contrasting experiences from South Asia and sub-Saharan Africa. Food Policy 2007, 32, 413-435. [CrossRef]

10. Kurosaki, T. Crop choice, farm income, and political control in Myanmar. J. Asia Pac. Econ. 2008, 13, $180-203$. [CrossRef]

11. Dorosh, P.A. Trade Liberalization and National Food Security: Rice Trade between Bangladesh and India. World Dev. 2001, 29, 673-689. [CrossRef]

12. Bell, A.R.; Bryan, E.; Ringler, C.; Ahmed, A. Rice productivity in Bangladesh: What are the benefits of irrigation? Land Use Policy 2015, 48, 1-12. [CrossRef]

13. Fiedler, J.L. Food crop production, nutrient availability, and nutrient intakes in Bangladesh: Exploring the agriculture-nutrition nexus with the 2010 Household Income and Expenditure Survey. Food Nutr. Bull. 2014, 35, 487-508. [CrossRef] [PubMed]

14. Ganesh-Kumar, A.; Prasad, S.K.; Pullabhotla, H. Supply and Demand for Cereals in Bangladesh, 2010-2030; International Food Policy Research Institute: Washington, DC, USA, 2012.

15. Dev, S.M.; Sharma, A.N. Food Security in India: Performance, Challenges and Policies; Oxfam India Working Paper Series; Oxfam India: New Delhi, India, 2010.

16. Chen, M. Developing Myanmar Agriculture. Southeast Asia 1997, 2, 18-26.

17. Haggblade, S.; Boughton, D.; Cho, K.M.; Denning, G.; Kloeppinger-Todd, R.; Oo, Z.; Sandar, T.M.; Than, T.M.; Wai, N.E.M.A.; Wilson, S.; et al. Strategic choices shaping agricultural pereormance and food security in Myanmar. J. Int. Aff. 2014, 67, 55-71.

18. Rammohan, A.; Pritchard, B. The Role of Landholding as a Determinant of Food and Nutrition Insecurity in Rural Myanmar. World Dev. 2014, 64, 597-608. [CrossRef]

19. Moe, A.K.; Yutaka, T.; Fukuda, S.; Kai, S. Impact of Market Liberalization on International Pulses Trade of Myanmar and India. J. Fac. Agric. Kyushu Univ. 2008, 53, 553-561.

20. Ahmad, M.D.; Kirby, M.; Islam, M.S.; Hossain, M.J.; Islam, M.M. Groundwater Use for Irrigation and its Productivity: Status and Opportunities for Crop Intensification for Food Security in Bangladesh. Water Resour. Manag. 2014, 28, 1415-1429. [CrossRef]

21. Miah, M.A.M.; Gaihre, Y.K.; Hunter, G.; Singh, U.; Hossain, S.A. Fertilizer Deep Placement Increases Rice Production: Evidence from Farmers' Fields in Southern Bangladesh. Agron. J. 2016, 108, 805-812. [CrossRef]

22. Smilovic, M.; Gleeson, T.; Siebert, S. The limits of increasing food production with irrigation in India. Food Secur. 2015, 7, 835-856. [CrossRef]

23. Sastry, R.K.; Rashmi, H.B.; Rao, N.H. Nanotechnology for enhancing food security in India. Food Policy 2011, 36, 391-400. [CrossRef]

24. Ali, A.M.S. Technological change in agriculture and land degradation in Bangladesh: A case study. Land Degrad. Dev. 2004, 15, 283-298. [CrossRef]

25. Nath, R.; Luan, Y.B.; Yang, W.M.; Yang, C.; Chen, W.; Li, Q.; Cui, X.F. Changes in Arable Land Demand for Food in India and China: A Potential Threat to Food Security. Sustainability 2015, 7, 5371-5397. [CrossRef]

26. Rahman, S. Six decades of agricultural land use change in Bangladesh: Effects on crop diversity, productivity, food availability and the environment, 1948-2006. Singap. J. Trop. Geogr. 2010, 31, 254-269. [CrossRef]

27. Ren, J.; Hou, F. Change traditional thinking about food grain production and use food equivalent in yield measurement. Acta Pratacult. Sin. 1999, 8, 55-75.

28. Amid, J. The dilemma of cheap food and self-sufficiency: The case of wheat in Iran. Food Policy 2007, 32, 537-552. [CrossRef] 
29. Mittal, S. Demand-Supply Trends and Projections of Food in India; Indian Council for Research on International Economic Relations: New Delhi, India, 2008.

30. Bucagu, C.; Vanlauwe, B.; Van Wijk, M.T.; Giller, K.E. Resource use and food self-sufficiency at farm scale within two agro-ecological zones of Rwanda. Food Secur. 2014, 6, 609-628. [CrossRef]

31. Kim, K.; Burnett, K.; Ghimire, J. Assessing the potential for food and energy self-sufficiency on the island of Kauai, Hawaii. Food Policy 2015, 54, 44-51. [CrossRef]

32. FAO. Implications of Economic Policy for Food Security: A Training Manual; FAO: Rome, Italy, 1999.

33. Tang, H. Chian's grain self-sufficiency strategy in the new situation. Issues Agric. Econ. 2014, 2, 4-10.

34. Clapp, J. Food self-sufficiency: Making sense of it, and when it makes sense. Food Policy 2017, 66, 88-96. [CrossRef]

35. FAO. Food Balance Sheets. A Handbook; FAO: Rome, Italy, 2001.

36. Ang, B.W. LMDI decomposition approach: A guide for implementation. Energy Policy 2015, 86, $233-238$. [CrossRef]

37. Liu, Y.; Gao, C.; Pan, Y.; Gao, Y. Investigating contribution factors to China's grain output increase based on LMDI model during the period 1980 to 2010. J. Nat. Resour. 2014, 29, 1709-1720.

38. Zhou, Z.; Zheng, M. Influential factors decomposition for China's grain yield based on logarithmic mean divisia index method. Trans. Chin. Soc. Agric. Eng. 2015, 31, 1-6.

39. Feng, Z.; Sun, T.; Yang, Y. Study on the spatiotemporal patterns and contribution factors of China's grain output increase during 2003-2013. J. Nat. Resour. 2016, 31, 895-907.

40. Li, T.X.; Balezentis, T.; Cao, L.J.; Zhu, J.; Krisciukaitiene, I.; Melnikiene, R. Are the Changes in China's Grain Production Sustainable: Extensive and Intensive Development by the LMDI Approach. Sustainability 2016, 8, 1198. [CrossRef]

41. The Daily Star. No Rice Imports in Last Two Years Bangladesh. Available online: http:/ /www.thedailystar. net/newspaper (accessed on 1 November 2017).

42. Chen, Y. Research on Development of Export Trade of Myanmar Rice; Guangxi University: Nanning, China, 2014.

43. Thein, M.; Soe, M.M. Economic reforms and agricultural development in Myanmar. ASEAN Econ. Bull. 1998, 15, 13-30. [CrossRef]

44. Paul, B.K. Coping mechanisms practised by drought victims (1994/5) in North Bengal, Bangladesh. Appl. Geogr. 1998, 18, 355-373. [CrossRef]

45. MOSPI. Statistical Year Book Inida 2015; Ministry of Statistics \& Programme Implementation, Government of India: New Delhi, India, 2016.

46. BBS. Yearbook of Agricultural Statistics; Bangladesh Bureau of Statistics, Statistics and Informatics Division: Dhaka, Bangladesh, 2015.

47. Mainuddin, M.; Kirby, M. National food security in Bangladesh to 2050. Food Secur. 2015, 7, $633-646$. [CrossRef]

48. Kyi, K.N. Modernization of Burmese agriculture: Problems and prospects. Southeast Asian Aff. 1982, 9, 115-131. [CrossRef]

49. Hossain, M. Shallow tubewell, Boro rice, and their impact on food security in Bangladesh. In Proven Success in Agricultural Development: An IFPRI 2020 Book; Spielman, D.J., Pandya-Lorch, R., Eds.; International Food Policy Research Institute: Washington, DC, USA, 2010; p. 245.

50. Larson, D.W.; Jones, E.; Pannu, R.S.; Sheokand, R.S. Instability in Indian agriculture-A challenge to the Green Revolution technology. Food Policy 2004, 29, 257-273. [CrossRef]

51. Kong, Z. Myanmar's food security and its policies. Southeast Asian South Asian Stud. 2010, 4, 46-50.

52. Qian, S.; Hou, M. Study on the evolution of the agricultural policy and food security in Myanmar. Southeast Asian Stud. 2013, 3, 24-30.

53. DAHD\&F. National Livestock Policy, 2013; Ministry of Agriculture, Government of India: New Delhi, India, 2013.

54. Pingali, P. Westernization of Asian diets and the transformation of food systems: Implications for research and policy. Food Policy 2007, 32, 281-298. [CrossRef]

55. Nonhebel, S.; Kastner, T. Changing demand for food, livestock feed and biofuels in the past and in the near future. Livest. Sci. 2011, 139, 3-10. [CrossRef]

56. FAOSTAT. Food and Agriculture Organization of the United Nations Statistics; FAO: Rome, Italy, 2017. 
57. Rao, C.H.H. Declining demand for foodgrains in rural India: Causes and implications. Econ. Political Wkly. 2000, 35, 201-206.

58. Deaton, A.; Dreze, J. Food and nutrition in India: Facts and interpretations. Econ. Political Wkly. 2009, 44, 42-65.

59. Grygus, A. Diets-Health, Ethics \& Religion; Clovegarden: La Crescenta, CA, USA, 2017.

60. Swaminathan, M.S. Food Insecurity Atlas of Rural India; M.S. Swaminathan Research Foundation and World Food Program: Chennai, India, 2008.

61. Mahadevan, R.; Suardi, S. Is there a role for caste and religion in food security policy? A look at rural India. Econ. Model. 2013, 31, 58-69.

62. FAO; WFP; IFAD. The State of Food Insecurity in the World 2015; FAO: Rome, Italy, 2015.

63. IFPRI. Global Hunger Index: The Inequalities of Hunger; International Food Policy Research Institute: Washington, DC, USA; Dublin, Ireland; Bonn, Germany, 2017.

64. Karim, M.R.; Ishikawa, M.; Ikeda, M.; Islam, M.T. Climate change model predicts 33\% rice yield decrease in 2100 in Bangladesh. Agron. Sustain. Dev. 2012, 32, 821-830. [CrossRef]

65. Hussain, S.G. Assessing Impacts of Climate Change on Cereal Production and Food Security in Bangladesh. In Climate Change and Food Security in South Asia; Springer: New York, NY, USA, 2010; pp. 459-476.

66. Chen, C.-C.; McCarl, B.; Chang, C.-C. Climate change, sea level rise and rice: Global market implications. Clim. Chang. 2012, 110, 543-560. [CrossRef]

67. Mall, R.K.; Singh, R.; Gupta, A.; Srinivasan, G.; Rathore, L.S. Impact of climate change on Indian agriculture: A review. Clim. Chang. 2006, 78, 445-478. [CrossRef]

68. Wanjari, R.H.; Mandal, K.G.; Ghosh, P.K.; Adhikari, T.; Rao, N.H. Rice in India: Present status and strategies to boost its production through hybrids. J. Sustain. Agric. 2006, 28, 19-39. [CrossRef]

69. Danmei, C.; Xiaoming, C.; Yongjiang, L.; Jianxin, H. Influence of crop rotation on soil nutrients, microbial activities and bacterial community structures. Acta Pratacult. Sin. 2015, 24, 56-65.

70. CSO. Myanmar Statistical Yearbook 2016; Central Statistical Organization: Nay Pyi Taw, Myanmar, 2016.

(C) 2018 by the authors. Licensee MDPI, Basel, Switzerland. This article is an open access article distributed under the terms and conditions of the Creative Commons Attribution (CC BY) license (http:/ / creativecommons.org/licenses/by/4.0/). 